\title{
SEED ENCRUSTATION NOVEL TECHNIQUE FOR IMPROVING GROWTH PERFORMANCE IN ONION (ALLIUM CEPA L.) CV. PUSA RED
}

\author{
REHAN MALIK ${ }^{1}$ \& JITENDRA KUMAR S. HILLI ${ }^{2 *}$ \\ ${ }^{I}$ Technical Officer, AICRP on BSP-STR, Seed Unit, UAS, Dharwad \\ ${ }^{2}$ Special Officer (Seeds), Seed Unit, UAS, Dharwad
}

\begin{abstract}
APSTRACT
Seed encrustation is one of the important seed quality enhancement techniques adopted in small seeded crops to overcome the problem of slow, asynchronous and poor seedling establishment. An experiment was carried out to analyze the effect of three encrustation treatments and transplanting compared to control (no treatment and direct seed sowing). The treatment $T_{4}$ (Encrusted 1:1.2 buildup with Thiram and Mycorrhiza for direct seeding) showed higher field emergence at 15 DAS and plant stand @ 45 DAS (51.0\% and $71.99 \%$, respectively), bulb weight (122.92 g) and bulb yield (30.87 kg/plot) followed by transplanting, which recorded field emergence at 15 DAS and plant stand @ 45 DAS (49.0\% and $69.16 \%$, respectively), bulb weight $(118.10 \mathrm{~g})$ and bulb yield $(29.66 \mathrm{~kg} / \mathrm{plot})$. The lowest values of field emergence at 15 DAS and plant stand @ 45 DAS (38.65\% and $54.55 \%)$, bulb weight (93.15 g) and bulb yield (23.40 $\mathrm{kg} / \mathrm{plot}$ ) were observed in control (no treatment and direct seed sowing). Hence, the treatment encrusting 1:1.2 build up with thiram and Mycorrhiza and transplanting showed better performance than control in onion.
\end{abstract}

KEYWORDS: Encrustation, Field emergence, bulb yield, Mycorrhiza, transplanting

Received: Dec 04, 2020; Accepted: Dec 24, 2020; Published: Dec 31, 2020; Paper Id: IJASRDEC202018

\section{INTRODUCTION}

Onion (Allium cepa L.), a member of family "Amaryllidaceae" with $2 \mathrm{n}=16$ chromosomes is one of the major commercial bulb crops as well as staple vegetable of the world. It occupies a premier position amongst the vegetables due to its high preference in food, remunerative price and regular demand in the market. Worldwide onion is grown on 49.60 lakh ha area with 931.70 lakh MT (Metric tons) production and productivity of $18.80 \mathrm{MT} \mathrm{ha}^{-1}$. In last decade there was substantial increase in area $(53.49 \%)$, in production $(72.87 \%)$ and in productivity $(12.63 \%)$ indicating the potential of onion crop (Anon., 2019). India ranks first in area (13.05 lakh ha) and second in production (224.57 lakh MT) after China. It earns approximately Rs. 4000 crores annually from foreign exchange, which is about $70 \%$ of the fresh vegetables and $50 \%$ of total vegetables and fruits. Though onion production in India has increased exponentially by $300 \%$ in last two decades, the country still requires 333.90 lakh MT onion by 2050 with present consumption rate of $6.70 \mathrm{~kg}$ per capita, export (9\%), processing (6.75\%) and losses (20\%)(Anon, 2019).

Major onion growing states in India are Maharashtra, Karnataka, Madhya Pradesh, Rajasthan, Bihar, Odisha and Gujarat. Karnataka occupies the second position in area (1.95 lakh ha) and third position in production (29.87 lakh MT). In Karnataka, the major onion growing districts are Gadag, Chitradurga, Dharwad, Bijapur, Bagalkot and Haveri (Anon, 2019).

Major problem in onion is low quality seeds resulting in slow and asynchronous germination as well as seeds producing a high number of abnormal seedlings (Borowski and Michałek, 2006). Seedling establishment is 
an important factor in bulb production of onion, it largely depends on the seed germination and vigour. Onion seeds are small in size, irregular in shape hence pose problems in sowing due to singling and ultimately crop establishment. Seed enhancement techniques like film coating and encrusting help in giving uniform size, singling seed and facilitate better sowing. Thus helps to reduce emergence time, accomplish uniform emergence and give better crop stand (Ashraf and Foolad, 2005).

Encrusting is an important seed quality enhancement technique which involves gradual accumulation of layers of adhesive and inert material on the seed together with the application of insecticides, fungicides, nutrients and growth regulators. There is difference between pelleted and encrusted seeds, while both differ by change in their size and weight, encrusted seeds have the same shape as that of original seeds, but pelleted seeds become completely spherical. Encrustment on seed is generally used in circumstances $v i z$, when growers primarily intend to avoid double or multiple seeds during sowing and to maintain exact and consistent seed spacing. Further, encrusting enables onion seed for direct seeding and raising, thereby saving time up to 20-25 days. The sowing period is very short in onion, especially under rainfed situation if monsoon fails seeds are left over which need to be stored in cold storage for further use adding to maintenance cost.Keeping in view of the above facts, the present investigation was carried with an objective to find out the effect of seed encrustation technique on field performance of onion.

\section{MATERIAL AND METHODS}

Laboratory experiment was carried out at Seed Quality and Research Laboratory of National Seed Project, Seed Unit, University of Agricultural Sciences, Dharwad, to know the effect of seed encrustation techniques on yield and seed quality of onion cv. Pusa red. Five kilograms of freshly harvested seeds of onion cv. Pusa red was collected and sent to INCOTEC Pvt Ltd. for treating the seeds with the plant protectants/additives. The encrusted seed material was subjected to laboratory tests and field performance to assess the effect of seed encrustation under field conditions. The experiment was laid out in Randomized Block Design (RBD) with four replication and five treatments. The gross plot size was $5.0 \mathrm{~m}$ x $4.0 \mathrm{~m}$, and the spacing: 30 x $15 \mathrm{~cm}$ was followed with recommended package of practices to raise a healthy crop. Field observations on growth parameters i.e., field emergence (\%) 15 DAS and plant stand @ 45 DAS, number of leaves per plant, plant height $(\mathrm{cm})$ at harvest and yield attributes viz., final plant stand per plot (\%),bulb weight $(\mathrm{g})$, bulb diameter $(\mathrm{cm})$ and bulb yield per plot $(\mathrm{kg})$ were recorded. The data obtained was analysed following the methods described by Panse and Sukhatme (1985).

The different seed treatment combinations used for the experiment are as follows:

\begin{tabular}{|l}
\hline$T_{1}$ : No treatment/ Direct sowing \\
\hline$T_{2}$ : No treatment/ Transplanting \\
\hline$T_{3}$ :Encrusted 1:1.2 buildup with Thiram for direct seeding \\
\hline$T_{4}$ :Encrusted 1:1.2 buildup with Thiram and Mycorrhiza for direct seeding \\
\hline$T_{5}$ : Encrusted 1:1.2 buildup with Thiram and Genius coat TM for direct seeding \\
\hline
\end{tabular}

\section{RESULTS AND DISCUSSION}

Effect of different seed encrustation treatments and transplanting showed significant differences when compared to control (No treatment/Direct sowing) in onion cv. Pusa red and the data is presented in Table 1. It was observed that treatment $\mathrm{T}_{4}$ 
(Encrusted 1:1.2 buildup with Thiram and Mycorrhiza for direct seeding) depicted higher (51.0\% and 71.99\%,respectively) field emergence percentage at 15 DAS and plant stand @ 45 DAS, followed by $\mathrm{T}_{2}$ (No treatment/ Transplanting) (49.0\% and $69.16 \%$,respectively), while the lowest values were noticed in $\mathrm{T}_{1}$ (Control : No treatment/ Direct sowing) ( $38.65 \%$ and $54.55 \%$, respectively).

Significant differences were noticed in plant height (Table 1) at harvest and number of leaves/plant which recorded higher values $\left(53.55 \mathrm{~cm}\right.$ and 8 number of leaves) in $\mathrm{T}_{4}$ (Encrusted 1:1.2 buildup with Thiram and Mycorrhiza for direct seeding), followed by $\left(51.45 \mathrm{~cm}\right.$ and 7 number of leaves) in $\mathrm{T}_{2}$ (No treatment/ Transplanting). The treatment $\mathrm{T}_{1}$ (Control: No treatment/ Direct sowing) recorded lower parameters $(40.58 \mathrm{~cm}$ and 6 number of leaves). The final plant stand differed significantly with higher value $(85.46 \%)$ in $\mathrm{T}_{2}$ (No treatment/ Transplanting) followed by $\left(82.0 \%\right.$ ) in $\mathrm{T}_{4}$ (Encrusted $1: 1.2$ buildup with Thiram and Mycorrhiza for direct seeding) and lower value $(67.41 \%)$ in $\mathrm{T}_{1}$ (Control : No treatment/ Direct sowing).

The yield attributes viz., bulb weight $(\mathrm{g})$, bulb diameter $(\mathrm{cm})$ and bulb yield per plot $(\mathrm{kg})$ differed significantly (Table 2) and were found to be highest $\left(122.92 \mathrm{~g}, 12.68 \mathrm{~cm}\right.$ and $30.87 \mathrm{~kg}$, respectively) in $\mathrm{T}_{4}$ (Encrusted 1:1.2 buildup with Thiram and Mycorrhiza for direct seeding) which is also on par $\left(118.10 \mathrm{~g}, 12.18 \mathrm{~cm}\right.$ and $29.66 \mathrm{~kg}$, respectively) with $\mathrm{T}_{2}$ (No treatment/ Transplanting) and lower $\left(93.15 \mathrm{~g}, 9.61 \mathrm{~cm}\right.$ and $23.40 \mathrm{~kg}$, respectively) in $\mathrm{T}_{1}$ (Control :No treatment/ Direct sowing).

The beneficial effect of encrustation treatments might be through physiological and disease protection mechanism. The positive effect of thiram as a protective agent against various fungal invasions enhanced growth and development of the crop, which ultimately resulted in better crop yield. Similar observations were made by Srimathi et al. (2001) in pearl millet and Savitri et al., (1998) in groundnut. Lin (1982) reported better growth parameters of soybean in Mycorhizza and Genecoat treatments as compared to control. The results were also comparable with findings of Mewael (2008) in soybean.

The higher seedling emergence was due to beneficial effects and multiple modes of action (Hanson 2000; Mishra 1990; Oyarbide et al. 2001). Results were in confirmation with Dubey et al. 2007 wherein chilli seeds treated with Trichoderma strains increased field emergence and vigour index compared to that without seed treatment. Mukhtar (2008) investigated that okra seed treatment with $T$. harzianum gave the highest germination and reported that T. harzianum can be useful in enhancing the germination percentage as well as reduce loss caused by delayed germination. The present findings are in accordance with Ramalingam and Bollipo (2013) in chilli.

It could be seen from the present study, that the seed encrustation increased the field emergence, plant height and performance of bulb yield $(\mathrm{g})$ and yield related attributes in comparison to control. Mycorrhiza establishes symbiotic relationship with plants and plays a significant role in plant growth, disease protection and overall soil quality, which resulted in enhancement in germination, growth and development and ultimately the seed yield. The results are in concordance with Yadav (2018) in rapeseed and mustard.

\section{CONCLUSIONS}

Seed encrustation has significant effect on field emergence, plant height $(\mathrm{cm})$, number of leaves per plant and bulb weight (g) as compared to control. The encrustation based treatment $\left(\mathrm{T}_{4}\right.$ : Encrusted 1:1.2 buildup with Thiram and Mycorrhiza) for direct seeding performed better for yield and related parameters. It is therefore concluded that seed encrustation technology 
could be exploited for precision sowing, enhanced growth and development, disease protection and better seed yield in onion in particular and in small seeded crops in general.

\section{REFERENCES}

1. Anonymous, 2019, Horticulture Statistics Division, Department of Agriculture and Co-operation and Farmers Welfare, Ministry of Agriculture and Farmers Welfare, Govt. of India, New Delhi.

2. Ashraf, M., Foolad, M.R., 2005, Pre-sowing seed treatment-a shotgun approach to improve germination growth and crop yield under saline and non-saline conditions. Advances in. Agronomy, 88:223-271.

3. Borowski, E. and Michatek, S.,2006, The effect of seed conditioning on emergence and early growth of onion and carrot seedlings. Annales Universitatis Mariae Curie-Skolodowska Section EEE, Horticultura. 16:119-129.

4. Dubey, S. C., Suresha, M. and Singha, B., 2007, Evaluation of Trichoderma species against Fusarium oxysporum f. sp. ciceris for integrated management of chickpea wilt. Biological Control 40: 118-127.

5. Hanson, L. D., 2000, Reduction of Verticillium wilt symptoms in cotton following seed treatment with Trichoderma virens. J. Cotton. Sci. 4:224-231.

6. Lin, S. S., 1982, Seed quality aspects in soybean. Agronomia Sulriogradese, 18: 37-46.

7. Mewael, K. A., 2008, Effect of seed priming on storability, seed yield and quality (Glycine max (L.) Merill) M. Sc. (Agri) Thesis, Uni. Agri. Sci. Dharwad, Karnataka, India.

8. Mishra, A. K. and Dharamvir, H. S., 1990, Effect of fungicidal seed treatment against heavy inoculum pressure of certain fungi causing discolouration of paddy seeds. Indian Phytopathology, 43: 175-178.

9. Mukhtar, I., 2008, Influence of Trichoderma species on seed germination in okra. Mycopathology, 6 (1): 47-50.

10. Oyarbide, F., Osterrieth, M. L. and Cabello, M., 2001, Trichoderma koningii as a biomineralizing fungous agent of calcium oxalate crystals in typical Argiudolls of the Los Padres Lake natural reserve (Buenos Aires, Argentina). Microbiological Research, 156: 113-119.

11. Panse, V.G. and Sukhatme, P.V.,1985, Statistical methods for Agricultural workers, ICAR, New Delhi,167-174.

12. Ramalingam, R. and Bollipo, D. R. K., 2013, Influence of pulsed magnetic field on soybean (Glycine max L.) seed germination, seedling growth and soil microbial population. Indian Journal of Biochemistry and Biophysics, 50: 312-317.

13. Savitri, H., Sugunakar Reddy, M. and Muralimohan Reddy, B., 1998, Effect of seed treatment with fungicides and insecticides on seed borne fungi, storage insect pests,seed viability and seedling vigour of groundnut seed. Seed Res., 26(1): 62-72.

14. Srimathi, P., Malarkodi, K. and Sashtri, G., 2001, Influence of fungicides and insecticides on storability of pearl millet seeds. Madras Agric. J., 88(1-3): 16-21.

15. Yadav, R.D.S., 2018, Influence of Seed Encrustation on Germination, Establishment and Seed Yield in Rapeseed /Mustard. Int. J. Curr. Microbiol. App. Sci., Special Issue-7: 3539-3541. 
Table 1: Effect of Onion cv. Pusa Red Seed Encrustation on Plant Growth Characters

\begin{tabular}{|c|c|c|c|c|}
\hline Treatment & $\begin{array}{c}\text { Field } \\
\text { emergence } \\
\text { at } 15 \text { DAS } \\
(\%)\end{array}$ & $\begin{array}{c}\text { Field } \\
\text { emergence } \\
\text { at } 45 \mathrm{DAS} \\
(\%)\end{array}$ & $\begin{array}{c}\text { Plant } \\
\text { height at } \\
\text { harvest } \\
(\mathrm{cm})\end{array}$ & $\begin{array}{c}\text { Number of } \\
\text { leaves/ } \\
\text { plant }\end{array}$ \\
\hline $\mathbf{T}_{1}$ : No treatment/ Direct sowing & 38.65 & 54.55 & 40.58 & 6 \\
\hline $\mathbf{T}_{2}$ : No treatment/ Transplanting & 49.00 & 69.16 & 51.45 & 8 \\
\hline $\begin{array}{l}\mathbf{T}_{3} \text { : Encrusted } 1: 1.2 \text { buildup with Thiram for direct } \\
\text { seeding }\end{array}$ & 42.42 & 59.88 & 44.54 & 7 \\
\hline $\begin{array}{l}\text { T}_{4} \text { : Encrusted 1:1.2 buildup with Thiram and } \\
\text { Mycorrhiza for direct seeding }\end{array}$ & 51.00 & 71.99 & 53.55 & 8 \\
\hline $\begin{array}{l}\text { T5: Encrusted 1:1.2 buildup with Thiram and Genius } \\
\text { coat TM for direct seeding }\end{array}$ & 45.65 & 64.43 & 47.93 & 7 \\
\hline SEm \pm & 1.56 & 2.20 & 1.64 & 0.25 \\
\hline CD at $5 \%$ & 4.56 & 6.43 & 4.79 & 0.72 \\
\hline
\end{tabular}

Table 2: Effect of onion cv. Pusa Red Seed Encrustation on Yield Characters

\begin{tabular}{|c|c|c|c|c|}
\hline Treatment & $\begin{array}{c}\text { Final plant } \\
\text { stand/plot } \\
(\%)\end{array}$ & $\begin{array}{c}\text { Bulb weight } \\
\text { (g) }\end{array}$ & $\begin{array}{c}\text { Bulb } \\
\text { diameter } \\
(\mathrm{cm}) \\
\end{array}$ & $\begin{array}{c}\text { Bulb yield per } \\
\text { plot }(\mathrm{kg})\end{array}$ \\
\hline $\mathbf{T}_{\mathbf{1}}$ : No treatment/ Direct sowing & 67.41 & 93.15 & 9.61 & 23.40 \\
\hline $\mathbf{T}_{2}$ : No treatment/ Transplanting & 85.46 & 118.10 & 12.18 & 29.66 \\
\hline $\begin{array}{l}\text { T}_{3} \text { : Encrusted 1:1.2 buildup with Thiram for direct } \\
\text { seeding }\end{array}$ & 73.98 & 102.24 & 10.54 & 25.68 \\
\hline $\begin{array}{l}\mathbf{T}_{4}: \text { Encrusted 1:1.2 buildup with Thiram and } \\
\text { Mycorrhiza for direct seeding }\end{array}$ & 82.00 & 122.92 & 12.68 & 30.87 \\
\hline $\begin{array}{l}\text { T5: Encrusted 1:1.2 buildup with Thiram and Genius } \\
\text { coat TM for direct seeding }\end{array}$ & 77.85 & 110.02 & 11.35 & 27.63 \\
\hline SEm \pm & 2.04 & 3.76 & 0.39 & 0.95 \\
\hline CD at $5 \%$ & 5.95 & 10.99 & 1.13 & 2.76 \\
\hline
\end{tabular}


